\title{
How big is the influence of biogenic silicon pools on short-term changes in water-soluble silicon in soils? Implications from a study of a 10-year-old soil-plant system
}

\author{
Daniel Puppe $^{1}$, Axel Höhn ${ }^{1}$, Danuta Kaczorek ${ }^{1,2}$, Manfred Wanner ${ }^{3}$, Marc Wehrhan ${ }^{1}$, and Michael Sommer ${ }^{1,4}$ \\ ${ }^{1}$ Leibniz Centre for Agricultural Landscape Research (ZALF) e.V., Institute of Soil Landscape Research, \\ 15374 Müncheberg, Germany \\ ${ }^{2}$ Department of Soil Environment Sciences, Warsaw University of Life Science (SGGW), Nowoursynowska 159 , \\ 02-776 Warsaw, Poland \\ ${ }^{3}$ Brandenburg University of Technology Cottbus-Senftenberg, Department Ecology, 03013 Cottbus, Germany \\ ${ }^{4}$ Institute of Earth and Environmental Sciences, University of Potsdam, 14476 Potsdam, Germany \\ Correspondence to: Daniel Puppe (daniel.puppe@zalf.de)
}

Received: 5 May 2017 - Discussion started: 20 June 2017

Revised: 5 October 2017 - Accepted: 14 October 2017 - Published: 23 November 2017

\begin{abstract}
The significance of biogenic silicon (BSi) pools as a key factor for the control of Si fluxes from terrestrial to aquatic ecosystems has been recognized for decades. However, while most research has been focused on phytogenic $\mathrm{Si}$ pools, knowledge of other BSi pools is still limited. We hypothesized that different BSi pools influence short-term changes in the water-soluble Si fraction in soils to different extents. To test our hypothesis we took plant (Calamagrostis epigejos, Phragmites australis) and soil samples in an artificial catchment in a post-mining landscape in the state of Brandenburg, Germany. We quantified phytogenic (phytoliths), protistic (diatom frustules and testate amoeba shells) and zoogenic (sponge spicules) Si pools as well as Tironextractable and water-soluble Si fractions in soils at the beginning $\left(t_{0}\right)$ and after 10 years $\left(t_{10}\right)$ of ecosystem development. As expected the results of Tiron extraction showed that there are no consistent changes in the amorphous $\mathrm{Si}$ pool at Chicken Creek (Hühnerwasser) as early as after 10 years. In contrast to $t_{0}$ we found increased water-soluble $\mathrm{Si}$ and BSi pools at $t_{10}$; thus we concluded that BSi pools are the main driver of short-term changes in water-soluble Si. However, because total BSi represents only small proportions of water-soluble $\mathrm{Si}$ at $t_{0}(<2 \%)$ and $t_{10}(2.8-4.3 \%)$ we further concluded that smaller $(<5 \mu \mathrm{m})$ and/or fragile phytogenic Si structures have the biggest impact on short-term changes in water-soluble $\mathrm{Si}$. In this context, extracted phytoliths $(>5 \mu \mathrm{m})$ only amounted to about $16 \%$ of total Si con-
\end{abstract}

tents of plant materials of $C$. epigejos and $P$. australis at $t_{10}$; thus about $84 \%$ of small-scale and/or fragile phytogenic $\mathrm{Si}$ is not quantified by the used phytolith extraction method. Analyses of small-scale and fragile phytogenic Si structures are urgently needed in future work as they seem to represent the biggest and most reactive Si pool in soils. Thus they are the most important drivers of Si cycling in terrestrial biogeosystems.

\section{Introduction}

Various prokaryotes and eukaryotes are able to synthesize hydrated amorphous silica $\left(\mathrm{SiO}_{2} \cdot n \mathrm{H}_{2} \mathrm{O}\right)$ structures from monomeric silicic acid $\left(\mathrm{H}_{4} \mathrm{SiO}_{4}\right)$ in a process called biosilicification (Ehrlich et al., 2010). In terrestrial biogeosystems, biogenic silicon (BSi) synthesized by bacteria and fungi, plants, diatoms, testate amoebae and sponges can be found forming corresponding microbial, phytogenic, protophytic, protozoic and zoogenic BSi pools, respectively (Puppe et al., 2015; Sommer et al., 2006). BSi has been recognized as a key factor in the control of $\mathrm{Si}$ fluxes from terrestrial to aquatic ecosystems as it is in general more soluble compared to silicate minerals (e.g., Fraysse et al., 2006, 2009). These fluxes influence marine diatom production on a global scale (Dürr et al., 2011; Sommer et al., 2006; Struyf and Conley, 2012). Marine diatoms in turn can fix large quan- 
tities of carbon dioxide via photosynthesis, because up to $54 \%$ of the biomass in the oceans is represented by diatoms; thus diatoms have an important influence on climate change (Tréguer and De La Rocha, 2013; Tréguer and Pondaven, 2000).

While the importance of phytogenic Si pools for global Si fluxes has been recognized for three decades (e.g., Bartoli, 1983; Meunier et al., 1999; Street-Perrott and Barker, 2008), information on the other $\mathrm{BSi}$ pools is comparatively rare (Clarke, 2003). However, in recent publications the potential importance of diatoms, testate amoebae and sponge spicules in soils for Si cycling has been highlighted (Aoki et al., 2007; Creevy et al., 2016; Puppe et al., 2014, 2015, 2016). Furthermore, evidence arises that BSi pools are in disequilibrium at decadal timescales due to disturbances and perturbations by humans, e.g., by changes in forest management or farming practices (Barão et al., 2014; Keller et al., 2012; Vandevenne et al., 2015). As a consequence, BSi accumulation and BSi dissolution are not balanced, which influences Si cycling in terrestrial biogeosystems, not only on decadal but also on millennial scales (Clymans et al., 2011; Frings et al., 2014; Sommer et al., 2013; Struyf et al., 2010). Sommer et al. (2013), for example, found the successive dissolving of a relict phytogenic Si pool to be the main source of dissolved $\mathrm{Si}$ in soils of a forested biogeosystem. Due to the fact that the continuous decomposition of this relict phytogenic $\mathrm{Si}$ pool is not compensated by an equivalent buildup by recent vegetation the authors concluded that a BSi disequilibrium occurred on a decadal scale. On a millennial scale Clymans et al. (2011) estimated the total amorphous Si storage in temperate soils to be decreased by approximately $10 \%$ since the onset of agricultural development about 5000 years ago. This decrease does not only have consequences for land-ocean $\mathrm{Si}$ fluxes but also influences agricultural used landscapes, because $\mathrm{Si}$ is a beneficial element for many crops (e.g., Epstein, 2009; Ma and Yamaji, 2008).

For a better understanding of BSi dynamics, chronosequence studies are well suited, because they allow us to analyze time-related changes in BSi pools during biogeosystem development. In the present study we analyzed various BSi pools in differently aged soils of an initial artificial catchment (Chicken Creek; Hühnerwasser) in a post-mining landscape in NE Germany. Chicken Creek represents a study site with defined initial conditions and offers the rare opportunity to monitor BSi dynamics from the very beginning. Former studies at this site revealed (i) a formation of protophytic (diatom frustules), protozoic (testate amoeba shells) and zoogenic (sponge spicules) Si pools within a short time $(<10$ years) and (ii) a strong relation of spatiotemporal changes in protistic (diatoms and testate amoebae) BSi pools to the vegetation, because plants provide, e.g., rhizospheric micro-habitats including enhanced food supply (Puppe et al., 2014, 2016). From these results it can be concluded that vegetated spots in particular represent hotspots of BSi accumulation of various origin at initial biogeosystem sites (compare Wanner and
Elmer, 2009). Furthermore, construction work with large machines resulted in differently structured sections of Chicken Creek with slight differences in abiotic conditions (for details see Sect. 2.1.) (Gerwin et al., 2010). These differences in turn lead to section-specific vegetation dynamics at Chicken Creek (Zaplata et al., 2010).

Knowledge about $\mathrm{BSi}$ accumulation dynamics is crucial for the understanding of Si cycling in terrestrial biogeosystems. We regard water-extractable Si as a useful proxy for desilication and biological uptake (plants, testate amoebae etc.). In addition, we used an alkaline extractant (Tiron) to detect eventual short-term changes in the amorphous Si fraction. We hypothesized that (i) BSi pools influence short-term changes in water-soluble $\mathrm{Si}$ in initial soils but not short-term changes in amorphous $\mathrm{Si}$ fractions, (ii) the phytogenic $\mathrm{Si}$ pool is the most prominent one in size and thus the biggest driver of short-term changes in water-soluble $\mathrm{Si}$, and (iii) BSi pool changes are section-specific, i.e., related to vegetation dynamics. The aims of the present study were (i) to quantify various BSi pools, i.e., protophytic, protozoic, zoogenic and phytogenic Si pools, during initial soil and ecosystem development; (ii) to analyze potential section-specific short-term changes in these BSi pools after a decade of ecosystem development; and (iii) to evaluate the influence of different BSi pools on water-soluble $\mathrm{Si}$ in these soils.

\section{Material and methods}

\subsection{Study site}

The study site Chicken Creek $\left(51^{\circ} 36^{\prime} 18^{\prime \prime} \mathrm{N}, 14^{\circ} 15^{\prime} 58^{\prime \prime} \mathrm{E}\right)$ represents an artificial catchment in a post-mining landscape located in the active mining area of Welzow South (lignite open-cast mining, $150 \mathrm{~km}$ southeast of Berlin) in the state of Brandenburg, Germany (Kendzia et al., 2008; Russell et al., 2010). Climate at Chicken Creek is characterized by an average air temperature of $9.6^{\circ} \mathrm{C}$ and an annual precipitation of $568 \mathrm{~mm}$ comprising data from 1981 to 2010 (Meteorological Station Cottbus, German Weather Service).

To construct the $\sim 6$ ha sized catchment a $1-3$ m thick base layer (aquiclude) of Tertiary clay was covered by a 2-3 m thick sandy, lignite- and pyrite-free Quaternary sediment serving as a water storage layer (aquifer) (Gerwin et al., 2010; Kendzia et al., 2008). Quaternary material was taken from a depth of 20 to $30 \mathrm{~m}$ during lignite mining process and its texture is classified as sand to loamy sand (Table 1) with low contents of carbonate (Gerwin et al., 2009, 2010; Russell et al., 2010). Dumping of material and construction work with large machines (e.g., stackers and bulldozers) resulted in differently structured sections of Chicken Creek. Generally, the catchment area can be divided into four sections: (i) an eastern part (ca. $1.8 \mathrm{ha}$ ), (ii) a western part (ca. 1.6 ha), (iii) a central trench (ca. 0.9 ha) separating the eastern from the western part and (iv) a southern part (ca. $1.5 \mathrm{ha}$ ) with a pond 
Table 1. Contents of skeleton $(>2 \mathrm{~mm})$, fine earth $(<2 \mathrm{~mm})$, sand, silt and clay fractions (upper $30 \mathrm{~cm}$ ) at the sampling points in western, eastern and southern sections at Chicken Creek $\left(t_{0}\right.$, calculations based on data of Gerwin et al., 2010). Minimal (min.) as well as maximal (max.) values, means $(\bar{x})$ and standard deviations (SD) are given.

\begin{tabular}{|c|c|c|c|c|c|c|}
\hline \multicolumn{2}{|c|}{ Section } & $>2 \mathrm{~mm}$ & $<2 \mathrm{~mm}$ & Sand & Silt & Clay \\
\hline & & \multicolumn{2}{|c|}{$\%$} & \multicolumn{3}{|c|}{$\%$} \\
\hline \multirow[t]{4}{*}{ West } & Min. & 9 & 80 & 77 & 7 & 5 \\
\hline & Max. & 20 & 91 & 88 & 13 & 10 \\
\hline & $\bar{x}$ & 13 & 87 & 83 & 10 & 7 \\
\hline & SD & 5 & 5 & 4 & 2 & 2 \\
\hline \multirow[t]{4}{*}{ East } & Min. & 2 & 77 & 69 & 6 & 4 \\
\hline & Max. & 23 & 98 & 91 & 20 & 11 \\
\hline & $\bar{x}$ & 13 & 87 & 82 & 11 & 7 \\
\hline & SD & 7 & 7 & 9 & 6 & 3 \\
\hline \multirow[t]{4}{*}{ South } & Min. & 0.2 & 84 & 78 & 7 & 4 \\
\hline & Max. & 17 & 99.8 & 89 & 17 & 8 \\
\hline & $\bar{x}$ & 8 & 92 & 83 & 11 & 6 \\
\hline & SD & 8 & 8 & 4 & 4 & 2 \\
\hline
\end{tabular}

at the lowest point (Fig. 1). Construction work was completed in September 2005 (time zero, $t_{0}$ ). Analyses subsequent to catchment completion indicated slight differences in abiotic conditions between the eastern and the western parts (in soil $\mathrm{pH}$, conductivity, skeleton content with soil particle diameter $>2 \mathrm{~mm}$, proportions of sand, silt and clay, concentration of organic and inorganic carbon; Gerwin et al., 2010). The primary mineral component in all particle size fractions at $t_{0}$ was quartz (only small amounts of K-feldspar, plagioclase). Calcite comprised $0.5-4.5 \%$ of the initial sediment, dolomite was only detectable in a few samples with contents of $0.5 \%$, and magnesite $\left(\mathrm{MgCO}_{3}\right)$ was not detectable by mineralogical analysis (W. Schaaf, personal communication, 2011). For detailed information on the site construction and initial ecosystem development see Gerwin et al. (2010) and Schaaf et al. (2010), respectively.

\subsection{Soil sampling}

We used samples taken shortly after the construction of Chicken Creek $\left(2005, t_{0}\right)$ and after an ecosystem development period of about 10 years $\left(2015, t_{10}\right)$. For $t_{0}$ (no vegetation detectable) we assumed that biogenic siliceous structures were homogenously distributed across the whole area of Chicken Creek, i.e., no section-specific distribution of $\mathrm{BSi}$ (BSi $t_{0}$ east $\approx \mathrm{BSi} t_{0}$ west $\approx \mathrm{BSi} t_{0}$ south) at the beginning of ecosystem development (Puppe et al., 2016). This is why we did not sample all different sections of the catchment but took soil samples in six field replicates to quantify $\mathrm{BSi}$ pools at $t_{0}$. However, for $t_{10}$ we hypothesized section-specific differences in BSi pool quantities related to section-specific vegetation dynamics. To evaluate these differences after a decade of ecosystem development and to cover the biggest possible BSi accumulation in soil we focused on spots where Si-accumulating plant species, i.e., Calamagrostis epigejos and Phragmites australis, became dominant (Zaplata et al., 2010). Thus we took samples in the eastern (C. epigejos dominant) and western (mainly $C$. epigejos dominant, one spot with $P$. australis) and southern section (P. australis dominant) of Chicken Creek.

For an accurate description of changes in abiotic soil conditions and related phytogenic Si in every section, we took soil and plant samples in eastern, western and southern sections at $t_{0}$ as well as $t_{10}$. Erosion and deposition processes were clearly evident in the Chicken Creek catchment during the first years without plant cover. Substantial surface changes resulted from rill erosion, as aerial photographs (rill network) and a comparison of photogrammetry-based digital elevation models showed (Schneider et al., 2013). Interrill erosion did not lead to surface changes larger than about $20 \mathrm{~cm}$ during the first 5 years. Afterwards the establishment of an area-wide plant cover substantially reduces interrill erosion. Because all soil data at $t_{0}$ referred to a depth increment of $30 \mathrm{~cm}$ we reasonably assumed the same soil conditions for the sampled $t_{0}$ spots during the first years. Furthermore, we carefully selected sampling points at $t_{10}$ to be not influenced by erosion, i.e., at spots with low surface roughness and outside rills. Soil samples for the determination of soil properties and plant samples were taken in five (western and southern section) and six (eastern section) field replicates at $t_{0}$ and $t_{10}$ (Fig. 1). At every sampling point three undisturbed soil cores were taken with a core cutter (diameter $=3.4 \mathrm{~cm}$, depth $=5 \mathrm{~cm}$ ) and transferred into plastic bags. Bulk densities were calculated from dividing the weight of dried $\left(105^{\circ} \mathrm{C}\right)$ soil samples by their corresponding volumes.

\subsection{Determination of basic soil properties}

Soil samples were air dried and sieved and the fine earth fraction $(<2 \mathrm{~mm})$ was used for laboratory analyses. Soil $\mathrm{pH}$ was measured based on the DIN ISO method 10390 (1997) in $0.01 \mathrm{M} \mathrm{CaCl}_{2}$ suspensions at a soil-to-solution ratio of $1: 5$ $(w / v)$ after a 60 min equilibration period using a glass electrode. The total carbon content was analyzed by dry combustion using an elemental analyzer (Vario EL, Elementar Analysensysteme, Hanau, Germany). Carbonate $\left(\mathrm{CaCO}_{3}\right)$ was determined conductometrically using the Scheibler apparatus (Schlichting et al., 1995). Organic carbon $\left(\mathrm{C}_{\mathrm{org}}\right)$ was computed as the difference between total carbon and carbonate carbon. Analyses of basic soil properties were performed in two lab replicates per sample.

\subsubsection{Water-extractable $\mathrm{Si}\left(\mathrm{Si}_{\mathrm{H}_{2}} \mathrm{O}\right)$}

Water-extractable $\mathrm{Si}$ was determined based on a method developed by Schachtschabel and Heinemann (1967). Ten grams of dry soil $(<2 \mathrm{~mm})$ was weighed and put into $80 \mathrm{~mL}$ centrifuge tubes, and $50 \mathrm{~mL}$ distilled water was added with 


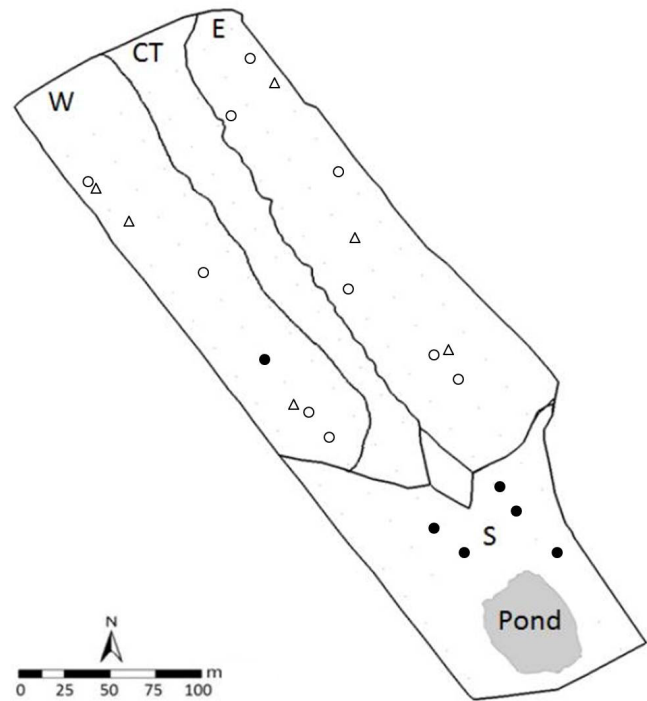

Figure 1. Map of Chicken Creek (W is the western section, CT is the central trench, $\mathrm{E}$ is the eastern section, $\mathrm{S}$ is the southern section with pond). Triangles indicate the sampling points used for $\mathrm{BSi}$ analyses at $t_{0}(n=6)$. Circles indicate the sampling points used for measurements of soil parameters (at $t_{0}$ and $t_{10}$ ) and plant analyses (only at $\left.t_{10}\right)(\mathrm{W}, n=5 ; \mathrm{E}, n=6 ; \mathrm{S}, n=5)$. Empty and filled circles represent sampling points where Calamagrostis epigejos and Phragmites australis became dominant. Note that the size of sampling points is not to scale.

three drops of a $0.1 \% \mathrm{NaN}_{3}$ solution to prevent microbial activity. Total extraction time was 7 days in which tubes were shaken by hand twice a day for $20 \mathrm{~s}$. Mechanical (constant) shaking by using, e.g., a roll mixer, was avoided to prevent abrasion of mineral particles from colliding during shaking (McKeague and Cline, 1963). The solutions were centrifuged ( $4000 \mathrm{rpm}, 20 \mathrm{~min})$, filtrated $(0.45 \mu \mathrm{m}$ polyamide membrane filters) and Si was measured with ICP-OES (ICPiCAP 6300 DUO, Thermo Fisher Scientific Inc). Analyses of water-extractable $\mathrm{Si}$ were performed in two lab replicates per sample.

\subsubsection{Tiron-extractable $\mathrm{Si}\left(\mathrm{Si}_{\text {Tiron }}\right)$, aluminum $\left(\mathrm{Al}_{\text {Tiron }}\right)$ and iron (Fe Tiron$_{\text {) }}$}

The Tiron $\left(\mathrm{C}_{6} \mathrm{H}_{4} \mathrm{Na}_{2} \mathrm{O}_{8} \mathrm{~S}_{2} \cdot \mathrm{H}_{2} \mathrm{O}\right)$ extraction followed the method developed by Biermans and Baert (1977) and modified by Kodama and Ross (1991). It has been used to quantify amorphous biogenic and pedogenic Si (Kendrick and Graham, 2004), although a partial dissolution of primary minerals is well known (Kodama and Ross, 1991; Sauer et al., 2006). The extraction solution was produced by dilution of $31.42 \mathrm{~g}$ Tiron with $800 \mathrm{~mL}$ of distilled water, followed by addition of $100 \mathrm{~mL}$ sodium carbonate solution $\left(5.3 \mathrm{~g} \mathrm{Na}_{2} \mathrm{CO}_{3}\right.$ $+100 \mathrm{~mL}$ distilled water) under constant stirring. The final $\mathrm{pH}$ of 10.5 was reached by adding small volumes of a $4 \mathrm{M}$ $\mathrm{NaOH}$ solution. For the extraction, $30 \mathrm{mg}$ of dry soil were weighed into $80 \mathrm{~mL}$ centrifuge tubes and a $30 \mathrm{~mL}$ aliquot of the Tiron solution was added. The tubes were then heated at $80^{\circ} \mathrm{C}$ in a water bath for $1 \mathrm{~h}$. The extracted solutions were centrifuged at $4000 \mathrm{rpm}$ for $30 \mathrm{~min}$ and filtrated $(0.45 \mu \mathrm{m}$ polyamide membrane filters, Whatman NL 17), and Si, Al and Fe were measured with ICP-OES. Analyses of Tironextractable $\mathrm{Si}, \mathrm{Al}$ and $\mathrm{Fe}$ were performed in three lab replicates per sample.

\subsection{Microscopical analyses of diatoms, sponge spicules and testate amoebae}

Fresh soil samples were homogenized by gentle turning of the plastic bags before air drying. Afterwards $2 \mathrm{~g}$ of fresh soil was taken per sample and stored in $8 \mathrm{~mL}$ of formalin (4\%). Subsequently, biogenic siliceous structures, i.e., diatom frustules, testate amoeba shells and sponge spicules (Fig. 2a-d), were enumerated in soil suspensions $(125 \mathrm{mg}$ fresh mass FM) received from serial dilution (1000-125 mg soil in $8 \mathrm{~mL}$ of water each) using an inverted microscope (OPTIKA XDS2 , objectives $20: 1$ and $40: 1$, equipped with a digital camera OPTIKAM B9).

\subsection{Determination of phytoliths in soil samples}

Ten grams of dry soil material $(<2 \mathrm{~mm})$ was processed in four steps (adapted from Alexandre et al., 1997). First organic matter was oxidized using $\mathrm{H}_{2} \mathrm{O}_{2}(30 \mathrm{Vol} . \%), \mathrm{HNO}_{3}$ $(65 \mathrm{Vol} . \%)$ and $\mathrm{HClO}_{4}(70 \mathrm{Vol} . \%)$ at $80^{\circ} \mathrm{C}$ until the reaction subsided. Secondly, carbonates and Fe oxides were dissolved by boiling the sample in $\mathrm{HCl}(10 \mathrm{Vol} . \%)$ for $30 \mathrm{~min}$. Thirdly, the $<2 \mu \mathrm{m}$ granulometric fraction was removed by dispersing the remaining solid phase of step 2 with 2 Vol.\% sodium hexametaphosphate solution (6-12 h), centrifugation at $1000 \mathrm{rpm}$ for 2-3 min and subsequent decantation. Finally, the phytoliths were separated by shaking the remaining solid phase of step 3 with $30 \mathrm{~mL}$ of sodium polytungstate $\left(\mathrm{Na}_{6}\left(\mathrm{H}_{2} \mathrm{~W}_{12} \mathrm{O}_{40}\right) \cdot \mathrm{H}_{2} \mathrm{O}\right)$ with a density of $2.3 \mathrm{~g} \mathrm{~cm}^{-3}$ and subsequent centrifugation at $3000 \mathrm{rpm}$ for $10 \mathrm{~min}$. Afterwards, the supernatant was carefully pipetted and filtered using $5 \mu \mathrm{m}$ Teflon filters. This step was repeated three times. The filter residue was washed with water, bulked, dried at $105^{\circ} \mathrm{C}$ and weighted.

\subsection{Quantification of biogenic Si pools}

In general, biogenic siliceous structures consist of hydrated amorphous silica $\left(\mathrm{SiO}_{2} \bullet n \mathrm{H}_{2} \mathrm{O}\right)$. We assumed an average water content of about $10 \%$ for these structures to avoid an overestimation of BSi pools (Mortlock and Froelich, 1989).

Protophytic Si pools (represented by diatom frustules) were quantified by multiplication of Si content per frustule with corresponding individual numbers (see Puppe et al., 2016). Protozoic Si pools (represented by testate amoebae) were quantified by multiplication of silica contents of diverse testate amoeba taxa (Aoki et al., 2007) with corresponding 

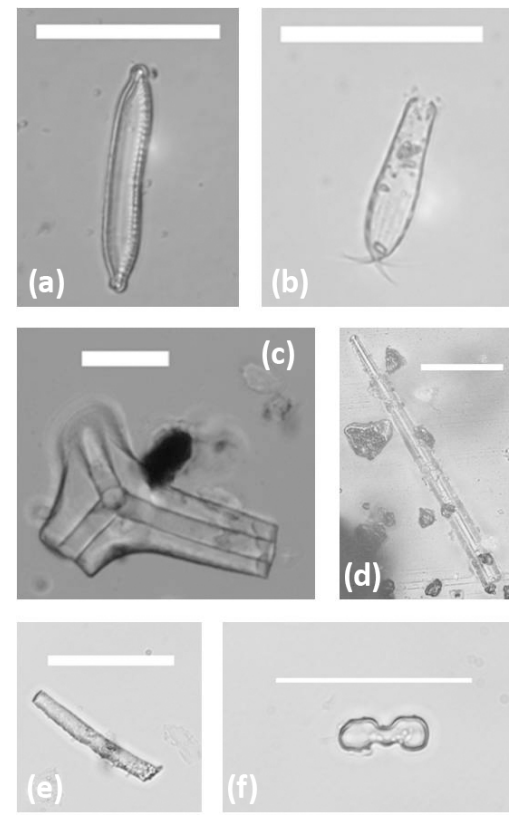

Figure 2. Micrographs (light microscope) of biogenic silica structures found at Chicken Creek. (a) Pennate diatom (valve view), (b) testate amoeba shell (Euglypha cristata), (c) and (d) sponge spicules (fragments), (e) elongate phytolith and (f) bilobate phytolith. All scale bars: $50 \mu \mathrm{m}$.

individual numbers (living plus dead individuals, for details see Puppe et al., 2014, 2015).

Zoogenic Si pools (represented by sponge spicule fragments) were calculated by multiplying volumes $\left(\mu \mathrm{m}^{3}\right)$ of the found spicule fragments with the density of biogenic Si $\left(2.35 \mathrm{~g} \mathrm{~cm}^{-3}\right)$ and summing up the results. Volume measurements were conducted using a laser scanning microscope (Keyence VK-X110, magnification 200-2000x) (details in Puppe et al., 2016). For laser scanning microscopy spicule fragments were taken from soil suspensions by micromanipulation, washed in distilled $\mathrm{H}_{2} \mathrm{O}$ and placed on clean object slides. Afterwards, air-drying images of spicule fragments were acquired (software Keyence VK-H1XVD) and analyzed (software Keyence VK-H1XAD).

Phytogenic Si pools were estimated by multiplying the numbers of found phytoliths with corresponding mean volumes $\left(\mu \mathrm{m}^{3}\right)$ of phytoliths, multiplying these results with the density of biogenic $\operatorname{Si}\left(2.35 \mathrm{~g} \mathrm{~cm}^{-3}\right)$ and summing up the results. Volume measurements with the laser scanning microscope of 30 typical elongate (Fig. 2e) and 30 typical bilobate phytoliths (Fig. 2f) resulted in mean volumes of $3765 \mu \mathrm{m}^{3}$ and $707 \mu \mathrm{m}^{3}$, respectively. For laser scanning microscopy extracted phytoliths were placed on clean object slides and images were acquired and analyzed analogous to sponge spicules. For bilobate phytoliths we measured the upper half per phytolith and doubled the result to obtain the corresponding total volume; thus we assumed bilobate phytoliths to be symmetric. We assumed phytoliths to consist of $95 \% \mathrm{SiO}_{2}$ and $5 \%$ other elements, e.g., carbon (Song et al., 2012) and elements like iron, aluminum or calcium (Buján, 2013).

BSi pools $\left(\mathrm{mg} \mathrm{m}^{-2}\right)$ were calculated considering bulk density $\left(\mathrm{g} \mathrm{cm}^{-3}\right)$, thickness $(5 \mathrm{~cm})$ and - for protistic and zoogenic Si pools - water content ( $\%$ of fresh mass) per soil sample. Silica $\left(M=60.08 \mathrm{~g} \mathrm{~mol}^{-1}\right)$ pools were converted to $\mathrm{Si}\left(M=28.085 \mathrm{~g} \mathrm{~mol}^{-1}\right)$ pools by multiplication with $28 / 60$ (details in Puppe et al., 2014, 2015, 2016).

\subsection{Plant analyses}

Plant and litter samples of $C$. epigejos and P. australis were collected in the summer of 2015. In general, monomeric silicic acid $\left(\mathrm{H}_{4} \mathrm{SiO}_{4}\right)$ enters the plant via its roots and is carried in the transpiration stream towards transpiration termini. When water evaporates, silicic acid becomes supersaturated and is precipitated as hydrated silica in the form of phytoliths. The vast majority of $\mathrm{Si}$ in plants is located at the transpiration termini (e.g., leaves) in the aerial plant parts, while considerably less Si can be found in other plant portions like stems, roots and rhizomes. Sangster (1983), for example, found no significant $\mathrm{Si}$ depositions in rhizomes of $P$. australis. Consequently, we only analyzed the aboveground vegetation (including transpiration termini and stems). The collected plant material was washed with distilled water to remove adhering soil minerals and oven-dried at $45^{\circ} \mathrm{C}$ for $48 \mathrm{~h}$.

\subsubsection{Total Si content in plant materials}

Plant samples were milled using a knife mill (Grindomix GM 200, Retsch) in two steps: $4000 \mathrm{rpm}$ for $1 \mathrm{~min}$ and then $10000 \mathrm{rpm}$ for $3 \mathrm{~min}$. Sample aliquots of approximately $100 \mathrm{mg}$ were digested under pressure in PFA digestion vessels using a mixture of $4 \mathrm{~mL}$ distilled water, $5 \mathrm{~mL}$ nitric acid $(65 \%)$ and $1 \mathrm{~mL}$ hydrofluoric acid $(40 \%)$ at $190^{\circ} \mathrm{C}$ using a microwave digestion system (Mars 6, CEM). A second digestion step was used to neutralize the hydrofluoric acid with $10 \mathrm{~mL}$ of a $4 \%$ boric acid solution at $150^{\circ} \mathrm{C}$. Silicon was measured with ICP-OES (ICP-iCAP 6300 Duo, Thermo Fisher Scientific Inc) with an internal standard. To avoid contamination, plastic equipment was used during the entire procedure. Analyses of total Si content were performed in three lab replicates per sample.

\subsubsection{Determination of phytoliths in plants and litter}

Plant material was washed with distilled water and ovendried at $45^{\circ} \mathrm{C}$ for $48 \mathrm{~h}$. Removal of organic matter was conducted by burning the samples in a muffle furnace at $450{ }^{\circ} \mathrm{C}$ for $12 \mathrm{~h}$. Next, the material was subject to additional oxidation using $30 \% \mathrm{H}_{2} \mathrm{O}_{2}$ for $12 \mathrm{~h}$. The obtained material was filtered through a Teflon filter with a mesh size of $5 \mu \mathrm{m}$. The isolated phytoliths and siliceous cast $(>5 \mu \mathrm{m})$ were subject to analysis via polarized light microscopy (Nikon ECLIPSE LV100 microscope) for full characteristics. We used laser 
Table 2. Measured soil parameters (upper $5 \mathrm{~cm}$, means $(\bar{x})$ with standard deviation - SD) at the different sections of Chicken Creek.

\begin{tabular}{lllrrrrrrr}
\hline \multirow{2}{*}{ Age } & Section & & $\mathrm{Si}_{\mathrm{H}_{2} \mathrm{O}}$ & $\mathrm{Si}_{\text {Tiron }}$ & $\mathrm{Al}_{\text {Tiron }}$ & $\mathrm{Fe}_{\text {Tiron }}$ & $\mathrm{C}_{\text {org }}$ & $\mathrm{CaCO}_{3}$ & $\mathrm{pH}$ \\
\cline { 3 - 8 } & & \multicolumn{7}{c}{$\mathrm{g} \mathrm{m}^{-2}$} \\
\hline \multirow{2}{*}{$t_{0}$} & West & $\bar{x}$ & $\mathbf{0 . 7 0}$ & 524 & 312 & 249 & $237^{*}$ & 88 & $\mathbf{7 . 9}$ \\
& & $\mathrm{SD}$ & 0.10 & 95 & 24 & 33 & 156 & 72 & 0.1 \\
$t_{10}$ & West & $\bar{x}$ & $\mathbf{1 . 7 3}$ & 552 & 254 & 239 & $556^{*}$ & 101 & $\mathbf{7 . 4}$ \\
& & $\mathrm{SD}$ & 0.22 & 300 & 154 & 104 & 167 & 93 & 0.1 \\
\hline \multirow{2}{*}{$t_{0}$} & East & $\bar{x}$ & $0.87^{*}$ & $\mathbf{5 0 3}$ & $\mathbf{2 6 8}$ & $\mathbf{2 6 1}$ & $\mathbf{1 2 3}$ & 91 & $\mathbf{8 . 1}$ \\
& & $\mathrm{SD}$ & 0.48 & 281 & 151 & 130 & 38 & 79 & 0.2 \\
$t_{10}$ & East & $\bar{x}$ & $1.50^{*}$ & $\mathbf{1 9 6}$ & $\mathbf{1 2 2}$ & $\mathbf{1 5 1}$ & $\mathbf{3 9 6}$ & 30 & $\mathbf{7 . 1}$ \\
& & $\mathrm{SD}$ & 0.57 & 49 & 27 & 29 & 54 & 18 & 0.2 \\
\hline \multirow{2}{*}{$t_{0}$} & South & $\bar{x}$ & $\mathbf{0 . 8 4}$ & 399 & 232 & $238^{*}$ & $160^{*}$ & 174 & $\mathbf{8 . 3}$ \\
& & $\mathrm{SD}$ & 0.06 & 154 & 112 & 65 & 131 & 109 & 0.1 \\
$t_{10}$ & South & $\bar{x}$ & $\mathbf{2 . 2 4}$ & 317 & 147 & $157^{*}$ & $474^{*}$ & 126 & $\mathbf{7 . 4}$ \\
& & $\mathrm{SD}$ & 0.33 & 149 & 62 & 57 & 258 & 40 & 0.1 \\
\hline
\end{tabular}

Significant differences between $t_{0}$ and $t_{10}$ are each stated in bold (Mann-Whitney $U$ test, $p<0.05$ ) or marked with asterisks $(p<0.1)$ for the western, eastern and southern sections.

Table 3. Spearman's rank correlations between measured soil parameters and total BSi (upper $5 \mathrm{~cm}, n=6$ ) at Chicken Creek.

\begin{tabular}{lrrrrrrrr}
\hline & $\mathrm{Si}_{\mathrm{H}_{2} \mathrm{O}}$ & $\mathrm{Si}_{\text {Tiron }}$ & $\mathrm{Al}_{\text {Tiron }}$ & $\mathrm{Fe}_{\text {Tiron }}$ & $\mathrm{C}_{\text {org }}$ & $\mathrm{CaCO}_{3}$ & $\mathrm{pH}$ & $\mathrm{BSi}$ \\
\hline $\mathrm{Si}_{\mathrm{H}_{2} \mathrm{O}}$ & 1.000 & & & & & & & \\
$\mathrm{Si}_{\text {Tiron }}$ & -0.257 & 1.000 & & & & & & \\
$\mathrm{Al}_{\text {Tiron }}$ & -0.600 & $\mathbf{0 . 8 2 9}$ & 1.000 & & & & & \\
$\mathrm{Fe}_{\text {Tiron }}$ & -0.486 & 0.771 & $\mathbf{0 . 9 4 3}$ & 1.000 & & & & \\
$\mathrm{C}_{\text {org }}$ & 0.714 & 0.086 & -0.371 & -0.486 & 1.000 & & & \\
$\mathrm{CaCO}_{3}$ & 0.200 & 0.086 & -0.086 & -0.029 & 0.029 & 1.000 & & \\
$\mathrm{pH}$ & -0.600 & 0.200 & 0.486 & 0.543 & -0.771 & 0.543 & 1.000 & \\
$\mathrm{BSi}$ & $\mathbf{0 . 9 4 1}$ & -0.213 & -0.577 & -0.577 & $\mathbf{0 . 8 8 0}$ & 0.152 & -0.698 & 1.000 \\
\hline
\end{tabular}

Significant correlation coefficients are given in bold $(p<0.05)$.

scanning microscopy for measurements of the surface area $\left(\mu \mathrm{m}^{2}\right)$ of the 30 typical bilobate and 30 typical elongated phytoliths used for volume measurements (see Sect. 2.6) and calculated corresponding surface-area-to-volume ratios $(A / V$ ratios) as an indicator of the resistibility of these siliceous structures against dissolution. Higher $A / V$ ratios indicate a bigger surface area available for dissolution processes.

\subsection{Statistical analyses}

Correlations were analyzed using Spearman's rank correlation $\left(r_{s}\right)$. Significances in two-sample $(n=2)$ cases were verified with the Mann-Whitney $U$ test. For $k$-sample $(n>2)$ cases the Kruskal-Wallis analysis of variance (ANOVA) was used followed by pairwise multiple comparisons (Dunn's post hoc test). Statistical analyses were performed using software package SPSS Statistics (version 19.0.0.1, IBM Corp.).

\section{Results}

\subsection{Basic soil parameters}

Soils at the initial state $\left(t_{0}\right)$ showed organic carbon contents $\left(\mathrm{C}_{\text {org }}\right)$ in the upper $5 \mathrm{~cm}$ between 1.1 and $4.4 \mathrm{~g} \mathrm{~kg}^{-1}$ in the western section, 0.8 and $1.8 \mathrm{~g} \mathrm{~kg}^{-1}$ in the eastern section and 0.2 and $3.3 \mathrm{~g} \mathrm{~kg}^{-1}$ in the southern section. This corresponded to mean carbon stocks of $237 \mathrm{~g} \mathrm{~m}^{-2}$ (west), $123 \mathrm{~g} \mathrm{~m}^{-2}$ (east) and $160 \mathrm{~g} \mathrm{~m}^{-2}$ (south, Table 2). After 10 years $\left(t_{10}\right)$ of ecosystem development the $\mathrm{C}_{\text {org }}$ stocks increased up to a factor of $3\left(396-556 \mathrm{~g} \mathrm{~m}^{-2}\right.$ in the upper $\left.5 \mathrm{~cm}\right)$ from corresponding values at $t_{0}$. This resulted in a surprisingly high mean annual $\mathrm{CO}_{2}-\mathrm{C}$ sequestration rate of $27-32 \mathrm{~g} \mathrm{~m}^{-2}$ (upper $5 \mathrm{~cm}$ ). Hereby the largest $C_{\text {org }}$ stock changes were found in the western section of the area followed by the eastern section and the southern section (Table 2).

The carbonate contents $\left(\mathrm{CaCO}_{3}\right)$ at $t_{0}$ varied between means of $1.0 \mathrm{~g} \mathrm{~kg}^{-1}$ (west), $0.9 \mathrm{~g} \mathrm{~kg}^{-1}$ (east) and $1.8 \mathrm{~g} \mathrm{~kg}^{-1}$ (south). The corresponding stocks were $88 \mathrm{~g} \mathrm{~m}^{-2}$ (west), $91 \mathrm{~g} \mathrm{~m}^{-2}$ (east) and $174 \mathrm{~g} \mathrm{~m}^{-2}$ (south, Table 2). The carbon- 
Table 4. Surface areas, volumes and surface-to-volume ratios $(A / V)$ of different biogenic siliceous structures found at Chicken Creek.

\begin{tabular}{lrrrrrrrrr}
\hline & \multicolumn{2}{c}{ Surface area $\left(\mu \mathrm{m}^{2}\right)$} & & \multicolumn{2}{c}{ Volume $\left(\mu \mathrm{m}^{3}\right)$} & & \multicolumn{2}{c}{$A / V$ ratio } \\
\cline { 2 - 3 } & \multicolumn{2}{c}{ Min. } & Max. & & Min. & Max. & & Range & Mean (SD) \\
\hline Bilobate phytoliths & 216 & 3730 & & 36 & 2046 & & $0.7-9.8$ & $2.8(1.8)$ \\
Elongate phytoliths & 2302 & 22203 & & 390 & 14649 & & $0.6-5.9$ & $2.6(1.1)$ \\
Diatom frustules* & 351 & 9901 & & 347 & 28024 & & $0.3-3.3$ & $0.9(0.5)$ \\
TA shells* & 1229 & 5085 & & 900 & 15812 & & $0.2-2.7$ & $0.8(0.7)$ \\
Sponge spicules* & 305 & 16963 & & 291 & 59744 & & $0.3-1.6$ & $0.8(0.4)$ \\
Spicule fragments* & 2828 & 17268 & & 5255 & 34812 & & $0.5-0.6$ & $0.5(0.03)$ \\
\hline
\end{tabular}

* Data taken from Puppe et al. (2016).

ate pools in the western and eastern section were very similar, while the high carbonate values in the southern section were due to the original soil properties. At $t_{10}$ the distribution of carbonate was as follows: in the western section there was an increase of about $17 \%$ (from 88 to $101 \mathrm{~g} \mathrm{~m}^{-2}$ ), in the eastern part a distinct decrease of about $67 \%$ (from 91 to $30 \mathrm{~g} \mathrm{~m}^{-2}$ ) was detected and in the southern section again a decrease of about $28 \%$ (from 174 to $126 \mathrm{~g} \mathrm{~m}^{-2}$ ) was identified.

At $t_{0}$ the $\mathrm{pH}$ values of the soils showed a range between 7.9 and 8.3 (Table 2) with relatively low variation between the different sections. After 10 years the $\mathrm{pH}$ values decreased to $7.1-7.4$ in all sections.

\subsection{Water and Tiron extractions}

The mean water-soluble $\mathrm{Si}\left(\mathrm{Si}_{\mathrm{H}_{2} \mathrm{O}}\right)$ contents in the upper $5 \mathrm{~cm}$ showed low variation between the different sections at $t_{0}: 7.3 \mathrm{mg} \mathrm{kg}^{-1}$ (west), $7.2 \mathrm{mg} \mathrm{kg}^{-1}$ (east) and $8.6 \mathrm{mg} \mathrm{kg}^{-1}$ (south). The corresponding stock values were $0.7 \mathrm{~g} \mathrm{~m}^{-2}$ (west), $0.87 \mathrm{~g} \mathrm{~m}^{-2}$ (east) and $0.84 \mathrm{~g} \mathrm{~m}^{-2}$ (south) for all sections at $t_{0}$ (Table 2). After 10 years $\left(t_{10}\right)$ an overall significant increase of $\mathrm{Si}_{\mathrm{H}_{2} \mathrm{O}}$ from $t_{0}$ was found in each of the different sections. The corresponding stock values were $1.7 \mathrm{~g} \mathrm{~m}^{-2}$ (west), $1.5 \mathrm{~g} \mathrm{~m}^{-2}$ (east) and $2.2 \mathrm{~g} \mathrm{~m}^{-2}$ (south, Table 2).

At $t_{0}$ the mean Tiron-extractable $\mathrm{Si}$ contents in the upper $5 \mathrm{~cm}$ varied between $5.5 \mathrm{~g} \mathrm{~kg}^{-1}$ (west), $5.2 \mathrm{~g} \mathrm{~kg}^{-1}$ (east) and $4.1 \mathrm{~g} \mathrm{~kg}^{-1}$ (south). The related stock values were $524 \mathrm{~g} \mathrm{~m}^{-2}$ (west), $503 \mathrm{~g} \mathrm{~m}^{-2}$ (east) and $399 \mathrm{~g} \mathrm{~m}^{-2}$ (south, Table 2). After 10 years $\left(t_{10}\right)$ the Tiron-extractable Si content showed a slight increase in the western section to $6.5 \mathrm{~g} \mathrm{~kg}^{-1}$ $\left(552 \mathrm{~g} \mathrm{~m}^{-2}\right)$, while the concentration in the eastern section decreased significantly to $2.6 \mathrm{~g} \mathrm{~kg}^{-1}\left(196 \mathrm{~g} \mathrm{~m}^{-2}\right.$, Table 2). In the southern section only a slight decrease to $3.8 \mathrm{~g} \mathrm{~kg}^{-1}$ $\left(317 \mathrm{~g} \mathrm{~m}^{-2}\right)$ was found. The $\mathrm{Al}$ and $\mathrm{Fe}$-extractable Tiron contents followed the distribution of the Si concentrations with one exception in the western section, where contrary to $\mathrm{Si}$ the $\mathrm{Al}$ and the $\mathrm{Fe}$ contents slightly increased at $t_{10}$ (Table 2). $\mathrm{Si} / \mathrm{Al}$ ratios ranged between 1.6 and 2.2 at Chicken Creek. Tiron-extractable $\mathrm{Si}$ and $\mathrm{Al}$ fractions as well as Tiron-

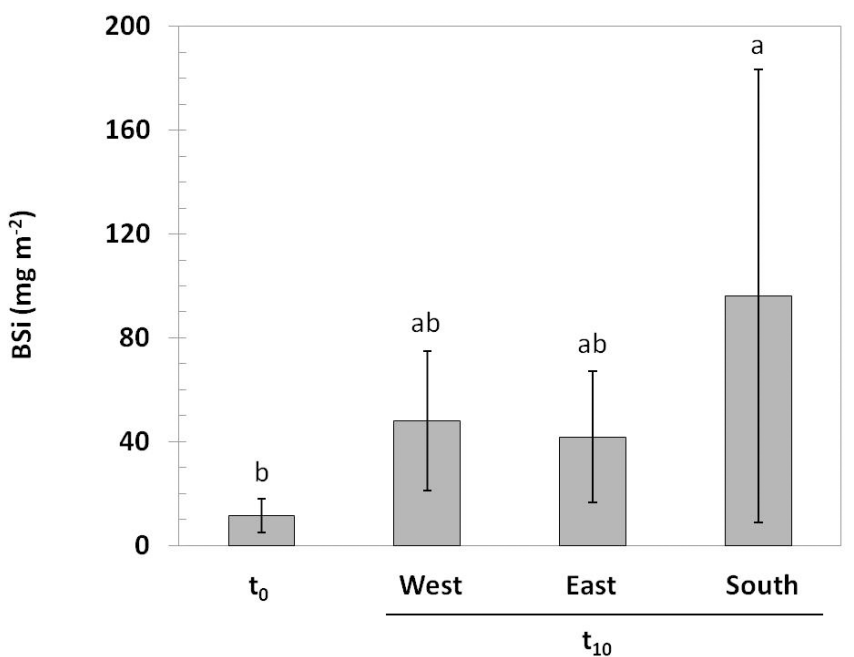

Figure 3. Total biogenic Si pools in soils (means \pm standard deviation, upper $5 \mathrm{~cm}$ ) at Chicken Creek at the end of construction work $\left(t_{0}\right)$ and after 10 years of ecosystem development (western, eastern and southern sections, $t_{10}$ ). Significant differences are indicated by different letters ( $p<0.05$, Kruskal-Wallis ANOVA with Dunn's post hoc test).

extractable $\mathrm{Al}$ and $\mathrm{Fe}$ fractions were strongly correlated (Table 3).

\subsection{Biogenic Si pools in soils}

In general, total biogenic Si pools increased in every section after 10 years of ecosystem development with statistically significant differences between $t_{0}\left(11.6 \pm 6.5 \mathrm{mg} \mathrm{Si} \mathrm{m}^{-2}\right)$ and the southern section at $t_{10}\left(96.0 \pm 87.2 \mathrm{mg} \mathrm{Si} \mathrm{m}^{-2}\right)$ (Fig. 3). Total BSi showed strong positive and statistically significant correlations to water-soluble $\mathrm{Si}$ (Table 3 ). Phytogenic (phytoliths $>5 \mu \mathrm{m}$ ) Si pools ranged from 0 to $18 \mathrm{mg} \mathrm{m}^{-2}$ (mean: $6.6 \mathrm{mg} \mathrm{m}^{-2}$ ) at $t_{0}$ and significantly increased to means of $20.7 \mathrm{mg} \mathrm{m}^{-2}$ (range: $7-52 \mathrm{mg} \mathrm{m}^{-2}$ ) and $12.9 \mathrm{mg} \mathrm{m}^{-2}$ (range: $14-15 \mathrm{mg} \mathrm{m}^{-2}$ ) at the eastern and southern sections over 10 years, respectively (Fig. 4a). Protophytic Si pools (diatom frustules) ranged from 0 to 

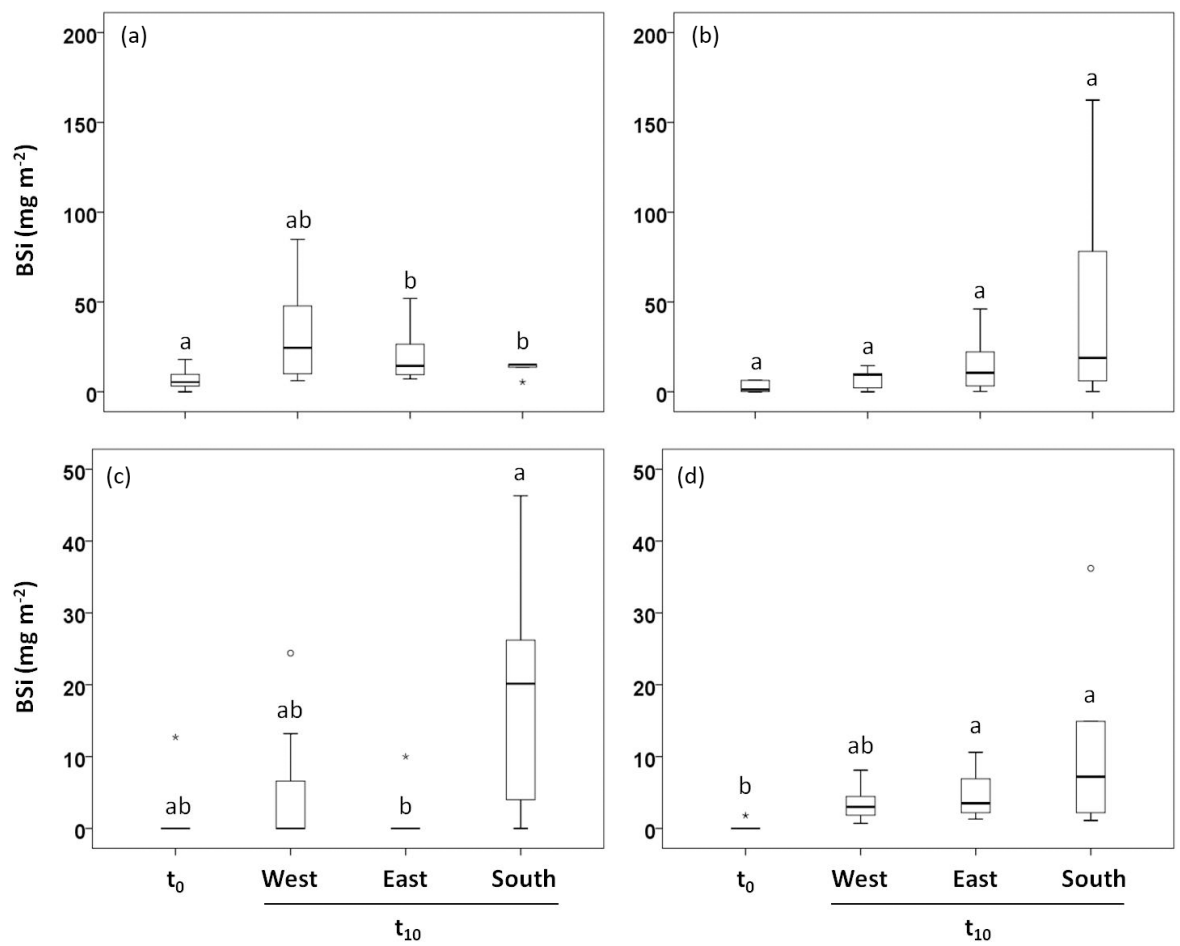

Figure 4. Box plots (top, middle and bottom lines of the boxes show the 25 th, 50 th and 75 th percentiles and whiskers represent $1.5 \times$ the interquartile ranges) of biogenic Si pools in soils (upper $5 \mathrm{~cm}$ ) at Chicken Creek at the end of construction work $\left(t_{0}\right)$ and after 10 years of ecosystem development (western, eastern and southern sections, $t_{10}$ ). (a) Phytogenic Si pools (phytoliths), (b) protophytic Si pools (diatom frustules), (c) zoogenic Si pools (sponge spicules) and (d) protozoic Si pools (testate amoeba shells). Significant differences are indicated by different letters ( $p<0.05$, Kruskal-Wallis ANOVA with Dunn's post hoc test). Circles and asterisks indicate outliers and extreme values, respectively. Note different scales for diagrams (a) and (b) and (c) and (d).

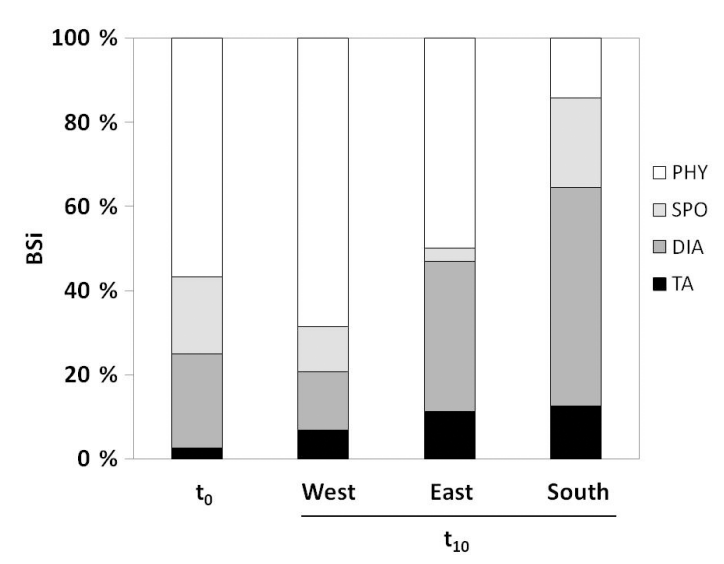

Figure 5. Proportions of phytoliths (PHY), sponge spicules (SPO), diatom frustules (DIA) and testate amoeba shells (TA) to total BSi in soils (upper $5 \mathrm{~cm}$ ) at Chicken Creek at $t_{0}$ and $t_{10}$. Note that total BSi pools differ in size (see Fig. 3).

$7 \mathrm{mg} \mathrm{m}^{-2}$ (mean: $2.6 \mathrm{mg} \mathrm{m}^{-2}$ ) at $t_{0}$ and increased up to a mean of $47.4 \mathrm{mg} \mathrm{m}^{-2}$ (range: $0.1-162 \mathrm{mg} \mathrm{m}^{-2}$ ) at $t_{10}$ (southern section) (Fig. 4b). At $t_{0}$ no sponge spicules were found with one exception representing an extreme value $\left(12.7 \mathrm{mg} \mathrm{m}^{-2}\right)$. After one decade of ecosystem development zoogenic Si pools increased to a maximum of $46 \mathrm{mg} \mathrm{m}^{-2}$ in the southern section $\left(t_{10}\right)$ (Fig. 4c). Protozoic Si pools were zero at $t_{0}$, with one exception representing an extreme value $\left(1.8 \mathrm{mg} \mathrm{m}^{-2}\right)$, and significantly increased to $4.6 \mathrm{mg} \mathrm{m}^{-2}$ (range: $1-11 \mathrm{mg} \mathrm{m}^{-2}$ ) and $11.5 \mathrm{mg} \mathrm{m}^{-2}$ (range: $2-36 \mathrm{mg} \mathrm{m}^{-2}$ ) in the eastern and the southern sections at $t_{10}$, respectively (Fig. 4d).

At $t_{0}$ most $\mathrm{BSi}(>50 \%)$ is represented by phytoliths $>5 \mu \mathrm{m}$ followed by diatom frustules, sponge spicules and testate amoeba shells (Fig. 5). After 10 years of ecosystem development the proportion of the different BSi pools to total BSi changed. While the proportion of protozoic Si pools increased in all sections at $t_{10}$, the other BSi pools showed more variable changes over time. The proportion of phytogenic Si pools either increased (western section) or decreased (eastern and southern sections). In contrast, the proportion of protophytic Si pools decreased in the western section and increased in the eastern and southern sections. The proportion of zoogenic Si pools decreased in the western and eastern sections but increased slightly in the southern section at $t_{10}$. 

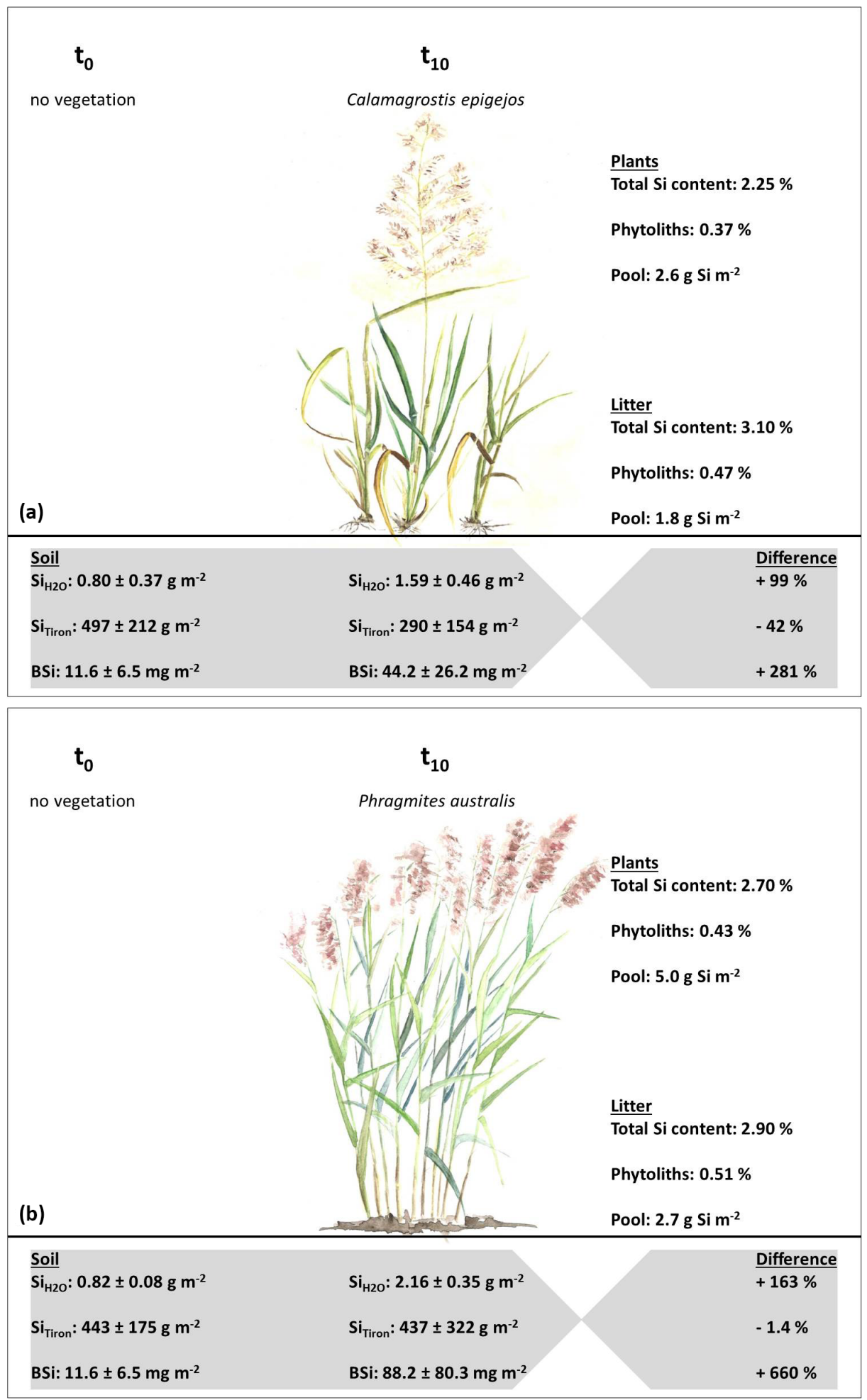

Figure 6. Comparison of water-soluble $\mathrm{Si}\left(\mathrm{Si}_{\mathrm{H}_{2} \mathrm{O}}\right)$, amorphous $\mathrm{Si}\left(\mathrm{Si}_{\mathrm{Tiron}}\right)$ fractions and total BSi in soils (means \pm standard deviation, upper $5 \mathrm{~cm}$ ), where Calamagrostis epigejos (a) and Phragmites australis (b) became dominant. Data are given for $t_{0}$ (no vegetation) and $t_{10}$ (C. epigejos, $P$. australis). For $t_{10}$ total plant Si contents, extracted phytogenic Si (phytoliths) contents and Si pools for $C$. epigejos and $P$. australis (plants and litter) are stated in addition. Paintings are from Cornelia Höhn, Müncheberg. 

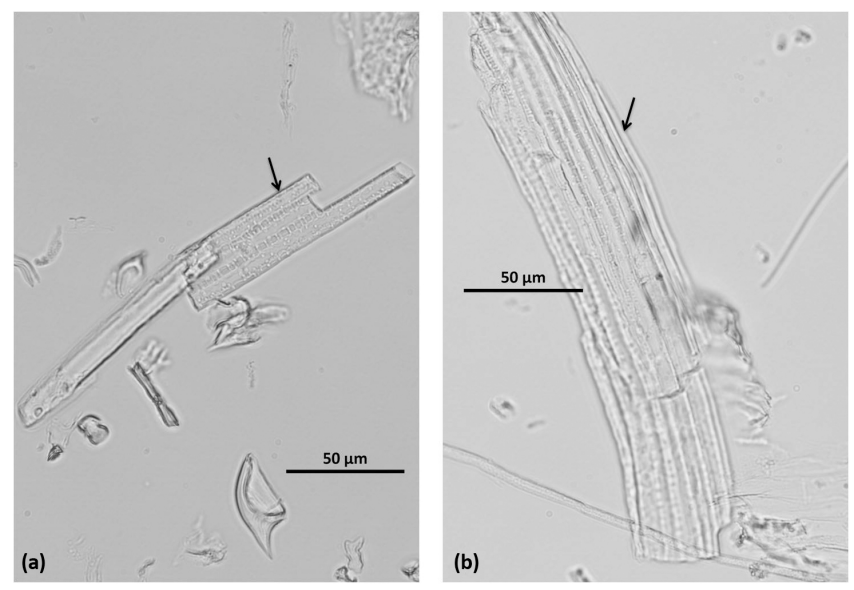

Figure 7. Micrographs of fragile phytogenic Si structures (arrows) of C. epigejos (a) and $P$. australis (b).

\subsection{Phytoliths and total Si content in plant materials}

The total content of $\mathrm{Si}$ was determined for two $\mathrm{Si}$ accumulating plant species, Calamagrostis epigejos and Phragmites australis, which dominate distinct catchment sections. For $C$. epigejos the mean total content of $\mathrm{Si}$ was $2.25 \%$ (range: $1.8-3.1 \%$ ), whereas for P. australis a mean total Si content of $2.70 \%$ (range: $2.0-3.2 \%$ ) was determined (Fig. 6a, b). For litter we found mean total Si contents of $3.1 \%$ (range: $2.8-3.3 \%$ ) and $2.9 \%$ (range: $1.7-3.2 \%$ ) for $C$. epigejos and $P$. australis, respectively.

Phytoliths $>5 \mu \mathrm{m}$ were also isolated from both plants, showing mean phytolith contents of $0.37 \%$ (range: $0.31-$ $0.46 \%$ ) and $0.43 \%$ (range: $0.37-0.50 \%$ ) for $C$. epigejos and P. australis, respectively (Fig. 6a, b). Regarding the total Si content of plants only about $16 \%$ of phytogenic $\mathrm{Si}$ were represented by the extracted phytoliths. Thus, smallscale $(<5 \mu \mathrm{m})$ and/or fragile (siliceous structures mostly thinner than $5 \mu \mathrm{m}$, but up to several hundred micrometers long, Fig. 7) phytogenic Si represented about $84 \%$ of total phytogenic $\mathrm{Si}$ in $C$. epigejos and $P$. australis, respectively. Mean extracted phytolith contents in plant litter were $0.47 \%$ (range: $0.35-0.70 \%$ ) and $0.51 \%$ (range: $0.41-0.59 \%$ ) for $C$. epigejos and $P$. australis.

Surface areas of 30 typical bilobate and 30 typical elongate phytoliths were in the ranges of 216 to $3730 \mu \mathrm{m}^{2}$ and 2302 to $22203 \mu^{2}$ (Table 4). The corresponding volumes of bilobate and elongate phytoliths were in the ranges of 36 to $2046 \mu \mathrm{m}^{3}$ and 390 to $14649 \mu^{3}$. Surface-to-volume ratios of bilobate and elongate phytoliths were in the ranges of 0.7 to 9.8 and 0.6 to 5.9 with means of 2.8 and 2.6.

\subsection{BSi and Si fractions under Calamagrostis epigejos and Phragmites australis}

Water-soluble Si fractions increased by 99 and $163 \%$ and total BSi by 281 and $660 \%$ after 10 years of ecosystem devel- opment in soils under C. epigejos and $P$. australis (Fig. 6a, b). In contrast, $\mathrm{Si}_{\text {Tiron }}$ decreased by 42 and $1.4 \%$ from $t_{0}$ to $t_{10}$ in soils under $C$. epigejos and $P$. australis. If we assume mean dry biomasses of 115 and $186 \mathrm{~g} \mathrm{~m}^{-2}$ for C. epigejos and P. australis (M. Wehrhan, personal communication, 2017) about 2.6 and $5.0 \mathrm{~g} \mathrm{Si} \mathrm{m}^{-2}$ are stored in the aboveground biomass at Chicken Creek at $t_{10}$. For $C$. epigejos and $P$. australis litter (mean dry biomasses of 59 and $94 \mathrm{~g} \mathrm{~m}^{-2}$ at $t_{10}$; M. Wehrhan, personal communication, 2017), we calculated corresponding pools of about 1.8 and $2.7 \mathrm{~g} \mathrm{Si} \mathrm{m}^{-2}$ at $t_{10}$.

\section{Discussion}

\subsection{Drivers of short-term changes in water-soluble $\mathrm{Si}$ at Chicken Creek}

In general, weathering of silicates represents the ultimate source of $\mathrm{Si}(\mathrm{OH})_{4}$ in terrestrial biogeosystems in the long term (Berner, 2003). In this context, the long-term accumulation of BSi can influence the total amorphous (Tironextractable) $\mathrm{Si}$ as it is known from forested catchments or old chronosequence soils (Conley et al., 2008; Kendrick and Graham, 2004; Saccone et al., 2008). Contrary, shortterm changes in BSi pools likely do not influence Tironextractable Si in initial soils (total BSi represents only 0.002$0.03 \%$ of Tiron-extractable Si at Chicken Creek). Thus, the major proportion of Tiron-extractable $\mathrm{Si}$ at Chicken Creek seems to be of pedogenic origin (e.g., Si included in $\mathrm{Al} / \mathrm{Fe}$ oxides / hydroxides). This is supported by relatively low $\mathrm{Si} / \mathrm{Al}$ ratios $(<5)$ indicating a minerogenic origin of Tironextractable $\mathrm{Si}$ instead of $\mathrm{BSi}$ as a source of $\mathrm{Si}_{\text {Tiron }}$ (Bartoli and Wilding, 1980). We further exclude changes in Tironextractable $\mathrm{Si}$ as the main driver of water-soluble $\mathrm{Si}$ at Chicken Creek in the short term, because (i) $\mathrm{Si}_{\text {Tiron }}$ and $\mathrm{Si}_{\mathrm{H}_{2} \mathrm{O}}$ showed no statistical relationship at all and (ii) a significant change of the Tiron-extractable Si fraction occurred only in the eastern section, whereas in the western and southern section $\mathrm{Si}_{\text {Tiron }}$ did not change significantly over time. We assume that these changes in $\mathrm{Si}_{\text {Tiron }}$ in the eastern section are related to abiotic conditions (soil $\mathrm{pH}$, conductivity, skeleton content, proportions of sand, silt and clay, concentration of organic and inorganic carbon), which were slightly different to the conditions of the western section at $t_{0}$ (Gerwin et al., 2010). Furthermore, we excluded atmospheric inputs as potential drivers of short-term changes in water-soluble Si at Chicken Creek. On the one hand, dust depositions (dry deposition) at Chicken Creek are very low $\left(73-230 \mathrm{mg} \mathrm{m}^{-2} \mathrm{~d}^{-1}\right)$ and only slightly above the annual average (70-90 $\mathrm{mg} \mathrm{m}^{-2} \mathrm{~d}^{-1}$ ) measured in the state of Brandenburg (Wanner et al., 2015). On the other hand, the total input of $\mathrm{Si}$ (as a lithogenic element) from precipitation (wet deposition) is negligible as well $\left(<1 \mathrm{~kg} \mathrm{Si} \mathrm{ha}^{-1} \mathrm{yr}^{-1}\right.$, Sommer et al., 2013). 
Our results indicate a strong relationship between watersoluble $\mathrm{Si}$ and total $\mathrm{BSi}$. In this context, two different causal chains can be discussed: either $\mathrm{SiO}_{2}$-synthesizing organisms are drivers of the amount of $\mathrm{Si}(\mathrm{OH})_{4}$ in the soil or - vice versa - the amount of water-soluble $\mathrm{Si}$ in the soils is the main driver of $\mathrm{SiO}_{2}$-synthesizing organisms as biosilicification is limited by $\mathrm{Si}(\mathrm{OH})_{4}$. Laboratory studies revealed that $\mathrm{SiO}_{2}$-synthesizing organisms, i.e., testate amoebae, can deplete the amount of $\mathrm{Si}(\mathrm{OH})_{4}$ in culture media due to biosilicification (Aoki et al., 2007; Wanner et al., 2016). However, Wanner et al. (2016) also showed that culture growth of $\mathrm{SiO}_{2}$-synthesizing testate amoebae was dependent on $\mathrm{Si}$ concentration in the culture media. Furthermore, in situ analyses showed that marine diatom blooms can deplete $\mathrm{Si}(\mathrm{OH})_{4}$ concentrations in the oceans (Hildebrand, 2008). In forested biogeosystems Puppe et al. (2015) found high individual numbers of $\mathrm{SiO}_{2}$-synthesizing testate amoebae at study sites with low amounts of $\mathrm{Si}(\mathrm{OH})_{4}$ and vice versa. However, it is unlikely that testate amoebae depleted amounts of $\mathrm{Si}(\mathrm{OH})_{4}$ at these sites, because corresponding protozoic $\mathrm{Si}$ pools are relatively small compared to phytogenic ones (Puppe et al., 2015; Sommer et al., 2013). Regarding vegetation and corresponding phytogenic Si pools, their influence on the amount of $\mathrm{Si}(\mathrm{OH})_{4}$ in soils has been shown in several studies (e.g., Bartoli, 1983; Farmer et al., 2005; Sommer et al., 2013). On the other hand, phytolith production is probably more influenced by the phylogenetic position of a plant than by environmental factors like temperature or $\mathrm{Si}$ availability (Hodson et al., 2005; Cooke and Leishman, 2012).

From our results and the discussion above we conclude short-term changes in water-soluble $\mathrm{Si}$ to be mainly driven by BSi. However, total BSi represents only small proportions of water-soluble $\mathrm{Si}$ at $t_{0}(<2 \%)$ and $t_{10}(<4.5 \%)$. From this result a question arises: where does the major part of the increase in water-soluble $\mathrm{Si}$ at Chicken Creek come from? We will discuss this question in Sect. 4.2 below.

\subsection{Sources of water-soluble Si at Chicken Creek}

From former results of BSi analyses in forested biogeosystems, we assumed the phytogenic Si pool to be the most prominent in size. In this context, results of Sommer et al. (2013) and Puppe et al. (2015) showed that phytogenic $\mathrm{Si}$ pools in soils of forested biogeosystems were up to several hundred times larger than protozoic Si pools. However, phytogenic Si pools in soils are surprisingly small compared to other BSi pools at Chicken Creek. Our findings can be attributed to at least two factors. Firstly, phytogenic Si is stored in a developing organic litter layer where it is temporarily protected against dissolution, and secondly, the used methods were not able to accurately quantify the total phytogenic Si pool, but only the larger ( $>5 \mu \mathrm{m})$ and more stable part.

Total Si and phytolith contents of litter samples at Chicken Creek did not differentiate from total $\mathrm{Si}$ and phytolith contents of plants. This fact indicates that litter decomposition and related $\mathrm{Si}$ release into the subjacent soil are relatively slow processes and we interpret our findings as an indication of a developing compartment of dead plant tissue above the mineral soil surface. Esperschütz et al. (2013) showed in a field experiment in initial soils near Chicken Creek that after 30 weeks only $50 \%$ of the $C$. epigejos litter was degraded, whereby degradation rates were highest in the first 4 weeks. Estimations of biomasses of $C$. epigejos and $P$. australis at Chicken Creek via remote sensing with an unmanned aerial system showed that the relation between phytogenic Si pools of plant biomass and litter biomass are almost the same for both plant species (factor about 1.5, based on the total area of Chicken Creek); i.e., Si in the plants was about one-third higher than in litter (M. Wehrhan, personal communication, 2017). At the sampling points about 1.8 and $2.7 \mathrm{~g} \mathrm{Si} \mathrm{m}^{-2}$ were stored in the litter of $C$. epigejos and $P$. australis at $t_{10}$, respectively, which is in the range of published data for annual $\mathrm{Si}$ input through litterfall in a short grass steppe (2.2$2.6 \mathrm{~g} \mathrm{Si} \mathrm{m}^{-2} \mathrm{yr}^{-1}$, Blecker et al., 2006).

Altogether, these results clearly underline our interpretation of a developing organic layer where litter accumulates and phytogenic Si is temporarily stored and protected against dissolution. Thus Si release is delayed and biologically controlled, as it can be observed at forested biogeosystems (Sommer et al., 2013). The Si pools in the aboveground biomass of $C$. epigejos $\left(2.6 \mathrm{~g} \mathrm{Si} \mathrm{m}^{-2}\right)$ and $P$. australis $\left(5.0 \mathrm{~g} \mathrm{Si} \mathrm{m}^{-2}\right)$ at Chicken Creek at $t_{10}$ are comparable to reported values of Great Plains grasslands $\left(2.2-6.7 \mathrm{~g} \mathrm{Si} \mathrm{m}^{-2}\right.$ in the aboveground biomass) (Blecker et al., 2006) and reach about $30 \%$ (C. epigejos) or $59 \%$ (P. australis) of published data for a beech forest $\left(8.5 \mathrm{~g} \mathrm{Si} \mathrm{m}^{-2}\right.$ in the aboveground biomass of Fagus sylvatica trees) in northern Brandenburg, Germany (Sommer et al., 2013), after (only) 10 years of ecosystem development.

Regarding methodological shortcomings of the used phytolith extraction procedure there are several aspects to be discussed. Wilding and Drees (1971), for example, showed that about $72 \%$ of leaf phytoliths of American beech ( $\mathrm{Fa}$ gus grandifolia) are smaller than $5 \mu \mathrm{m}$. This is in accordance with our findings. Phytoliths $>5 \mu \mathrm{m}$ only amounted to about $16 \%$ of total Si contents of plant materials of $C$. epigejos and P. australis; thus about $84 \%$ of phytogenic $\mathrm{Si}(<5 \mu \mathrm{m}$ and/or fragile phytogenic Si structures) are not quantified by the used phytolith extraction method. Watteau and Villemin (2001) found even smaller $(5-80 \mathrm{~nm})$ spherical grains of pure silica in leaf residues in topsoil samples of a forested biogeosystem. In addition, silica depositions can be found in intercellular spaces or in an extracellular (cuticular) layer (Sangster et al., 2001), whereat no recognizable phytoliths are formed. These structures might be too fragile for preservation in soils and are likely lost to a great extent in the used phytolith extraction procedure due to dissolution. Meunier et al. (2017) analyzed different phytolith morphotypes, e.g, silica bodies originating from cells of the upper epidermis, silica casts of trichomes or parenchyma/collenchyma 
cells and of durum wheat plant shoots. They found fragile subcuticular silica plates $(2-4 \mu \mathrm{m}$ thick, up to several hundred micrometers long and wide) to be the second most common phytolith morphotype. This is corroborated by our own findings as the biggest part (about $84 \%$ ) of total plant $\mathrm{Si}$ is represented by small-scale $(<5 \mu \mathrm{m})$ and/or fragile phytogenic $\mathrm{Si}$ in $C$. epigejos and $P$. australis. If we assume that total $\mathrm{Si}$ contents of plants at Chicken Creek are one-to-one reflected by phytogenic Si pools in soils, we can easily calculate these small-scale and fragile pools resulting in about 130 and $100 \mathrm{mg} \mathrm{m}^{-2}$ ( $84 \%$ of total, i.e., 156 and $119 \mathrm{mg} \mathrm{m}^{-2}$, phytogenic Si each) under $C$. epigejos and $P$. australis, respectively. These calculated phytogenic Si pools are about 13 (diatom frustules), 38 (testate amoeba shells) and 45 (sponge spicules) or 3 (diatom frustules) and 10 (testate amoeba shells, sponge spicules) times bigger than the other BSi pools at $C$. epigejos and $P$. australis sampling points. If we further assume an input of this phytogenic Si for at least 7 years (Zaplata et al., 2010) phytogenic Si might be the main driver of short-term changes in water-soluble $\mathrm{Si}$ at Chicken Creek. This is supported by relatively high surface-to-volume ratios of bilobate and elongate phytoliths. These ratios are about 3 times higher compared to ratios of other biogenic siliceous structures, i.e., testate amoeba shells, diatom frustules and sponge spicules.

In addition, $\mathrm{Si}$ pools represented by single siliceous platelets of testate amoeba shells have to be considered as well, as these platelets can be frequently found in freshwater sediments, for example (Douglas and Smol, 1987; Pienitz et al., 1995). Unfortunately, there is no available information on the quantity of such platelet pools in soils, but it can be assumed that these platelets can be frequently found in soils, as they are used by some testate amoeba genera (e.g., Schoenbornia, Heleopera) for shell construction (Meisterfeld, 2002; Schönborn et al., 1987). In general, it can be assumed that phytogenic Si structures $<5 \mu \mathrm{m}$ and single testate amoeba platelets (about $3-12 \mu \mathrm{m}$ in diameter, Douglas and Smol, 1987) are highly reactive due to their relatively high surface-to-volume ratios. However, to the best of our knowledge there is no publication available dealing with corresponding physicochemical analyses or dissolution kinetics of these siliceous structures. In general, experiments with phytoliths $(>5 \mu \mathrm{m})$ showed that surface areas and related dissolution susceptibilities are, for example, age-related due to changes in specific surface areas and the presence of organic matter bound to the surface of phytoliths (Fraysse et al., 2006, 2009).

\section{Conclusions}

Decadal changes in water-soluble $\mathrm{Si}$ at Chicken Creek are mainly driven by $\mathrm{BSi}$; thus $\mathrm{Si}$ cycling is already biologically controlled at the very beginning of ecosystem development. In this context, phytogenic Si plays a particularly prominent role. However, a developing organic layer (L horizon) at the soil surface temporarily protects phytogenic $\mathrm{Si}$ against dissolution, because phytogenic $\mathrm{Si}$ is still incorporated into plant structural elements (tissues). As a consequence a delaying biogenic Si pool is built up and Si release into the soil is retarded. Furthermore, established phytolith extraction methods alone are not suitable to quantify total phytogenic $\mathrm{Si}$ pools, as phytoliths $>5 \mu \mathrm{m}$ seem to be only a minor part of this pool (about $16 \%$ in the current study). In general, information on small-scale $(<5 \mu \mathrm{m})$ and/or fragile phytogenic $\mathrm{Si}$ structures is urgently needed as they seem to represent the biggest and most reactive $\mathrm{Si}$ pool in soils and thus are the most important drivers of Si cycling in terrestrial biogeosystems. Future work should focus on (i) the quantification of this pool, (ii) physicochemical analyses of its components and (iii) their dissolution kinetics in lab experiments. The combination of modern microscopical (SEM-EDX, laser scanning microscopy) (this study; Puppe et al., 2016; Sommer et al., 2013) and spectroscopical (FTIR and micro-FTIR spectroscopy) (Liu et al., 2013; Loucaides et al., 2010; Rosén et al., 2010) methods might introduce new insights to this field.

Data availability. All relevant data are presented within the paper. Underlying data can be obtained on request from the corresponding author.

Competing interests. The authors declare that they have no conflict of interest.

Acknowledgements. This study has been financed by the DFG project "Spatiotemporal dynamics of biogenic Si pools in initial soils and their relevance for desilication" (SO 302/7-1). Many thanks to Christian Buhtz and Reneé Ende for their excellent laboratory support. We would like to thank the members of the "Chicken Creek project" at BTU Cottbus-Senftenberg for providing soil samples from 2005 and organizational support. Vattenfall Europe Mining AG provided the research site. This study is a contribution to the Transregional Collaborative Research Centre 38 (SFB/TRR 38) financially supported by the German Research Council (DFG, Bonn) and the Brandenburg Ministry of Science, Research and Culture (MWFK, Potsdam). Last but not least we would like to thank the anonymous reviewers for their very helpful comments on our manuscript.

Edited by: Yakov Kuzyakov

Reviewed by: three anonymous referees

\section{References}

Alexandre, A., Meunier, J. D., Colin, F., and Koud, J. M.: Plant impact on the biogeochemical cycle of silicon and related weathering processes, Geochim. Cosmochim. Ac. 61, 677-682, 1997. 
Aoki, Y., Hoshino, M., and Matsubara, T.: Silica and testate amoebae in a soil under pine-oak forest, Geoderma, 142, 29-35, 2007.

Barão, L., Clymans, W., Vandevenne, F., Meire, P., Conley, D. J., and Struyf, E.: Pedogenic and biogenic alkaline-extracted silicon distributions along a temperate land-use gradient, Eur. J. Soil Sci., 65, 693-705, 2014.

Bartoli, F.: The biogeochemical cycle of silicon in two temperate forest ecosystems, Environ. Biogeochem. Ecol. Bull., 35, 469476, 1983.

Bartoli, F. and Wilding, L. P.: Dissolution of biogenic opal as a function of its physical and chemical properties, Soil Sci. Soc. Am. J., 44, 873-878, 1980.

Berner, R. A.: The long-term carbon cycle, fossil fuels and atmospheric composition, Nature, 426, 323-326, 2003.

Biermans, V. and Baert, L.: Selective extraction of the amorphous $\mathrm{Al}, \mathrm{Fe}$ and $\mathrm{Si}$ oxides using an alkaline Tiron solution, Clay Miner., 12, 127-135, 1977.

Blecker, S. W., McCulley, R. L., Chadwick, O. A., and Kelly, E. F.: Biologic cycling of silica across a grassland bioclimosequence, Global Biogeochem. Cy., 20, GB3023, https://doi.org/10.1029/2006GB002690, 2006.

Buján, E.: Elemental composition of phytoliths in modern plants (Ericaceae), Quatern. Int., 287, 114-120, 2013.

Clarke, J.: The occurrence and significance of biogenic opal in the regolith, Earth-Sci. Rev., 60, 175-194, 2003.

Clymans, W., Struyf, E., Govers, G., Vandevenne, F., and Conley, D. J.: Anthropogenic impact on amorphous silica pools in temperate soils, Biogeosciences, 8, 2281-2293, https://doi.org/10.5194/bg8-2281-2011, 2011.

Conley, D. J., Likens, G. E., Buso, D. C., Saccone, L., Bailey, S. W., and Johnson, C. E.: Deforestation causes increased dissolved silicate losses in the Hubbard Brook Experimental Forest, Global Change Biol. 14, 2548-2554, 2008.

Cooke, J. and Leishman, M. R.: Tradeoffs between foliar silicon and carbon-based defences: evidence from vegetation communities of contrasting soil types, Oikos, 121, 2052-2060, 2012.

Creevy, A. L., Fisher, J., Puppe, D., and Wilkinson, D. M.: Protist diversity on a nature reserve in NW England - with particular reference to their role in soil biogenic silicon pools, Pedobiologia, 59, 51-59, 2016.

DIN ISO 1039: Bodenbeschaffenheit: Bestimmung des pH-Wertes, Deutsches Institut für Normung, Beuth, Berlin, 1997.

Douglas, M. S. and Smol, J. P.: Siliceous protozoan plates in lake sediments, Hydrobiologia, 154, 13-23, 1987.

Dürr, H. H., Meybeck, M., Hartmann, J., Laruelle, G. G., and Roubeix, V.: Global spatial distribution of natural riverine silica inputs to the coastal zone, Biogeosciences, 8, 597-620, https://doi.org/10.5194/bg-8-597-2011, 2011.

Ehrlich, H., Demadis, K. D., Pokrovsky, O. S., and Koutsoukos, P. G.: Modern views on desilicification: biosilica and abiotic silica dissolution in natural and artificial environments, Chem. Rev., 110, 4656-4689, 2010.

Epstein, E.: Silicon: its manifold roles in plants, Ann. Appl. Biol. $155,155-160,2009$.

Esperschütz, J., Zimmermann, C., Dümig, A., Welzl, G., Buegger, F., Elmer, M., Munch, J. C., and Schloter, M.: Dynamics of microbial communities during decomposition of litter from pioneering plants in initial soil ecosystems, Biogeosciences, 10, 51155124, https://doi.org/10.5194/bg-10-5115-2013, 2013.
Farmer, V. C., Delbos, E., and Miller, J. D.: The role of phytolith formation and dissolution in controlling concentrations of silica in soil solutions and streams, Geoderma, 127, 71-79, 2005.

Fraysse, F., Pokrovsky, O. S., Schott, J., and Meunier, J. D.: Surface properties, solubility and dissolution kinetics of bamboo phytoliths, Geochim. Cosmochim. Ac., 70, 1939-1951, 2006.

Fraysse, F., Pokrovsky, O. S., Schott, J., and Meunier, J. D.: Surface chemistry and reactivity of plant phytoliths in aqueous solutions, Chem. Geol., 258, 197-206, 2009.

Frings, P. J., Clymans, W., Jeppesen, E., Lauridsen, T. L., Struyf, E., and Conley, D. J.: Lack of steady-state in the global biogeochemical Si cycle: emerging evidence from lake Si sequestration, Biogeochemistry, 117, 255-277, 2014.

Gerwin, W., Schaaf, W., Biemelt, D., Fischer, A., Winter, S., and Hüttl, R. F.: The artificial catchment 'Chicken Creek' (Lusatia, Germany) - A landscape laboratory for interdisciplinary studies of initial ecosystem development, Ecol. Eng., 35, 1786-1796, 2009.

Gerwin, W., Schaaf, W., Biemelt, D., Elmer, M., Maurer, T., and Schneider, A.: The Artificial catchment 'Hühnerwasser' (Chicken Creek): construction and initial properties, in: Ecosystem Development 1, edited by: Hüttl, R. F., Schaaf, W., Biemelt, D., and Gerwin, W., Brandenburg University of Technology Cottbus-Senftenberg, Germany, 1-58, 2010.

Hildebrand, M.: Diatoms, biomineralization processes, and genomics, Chem. Rev., 108, 4855-4874, 2008.

Hodson, M. J., White, P. J., Mead, A., and Broadley, M. R.: Phylogenetic variation in the silicon composition of plants, Ann. Bot. London, 96, 1027-1046, 2005.

Keller, C., Guntzer, F., Barboni, D., Labreuche, J., and Meunier, J. D.: Impact of agriculture on the Si biogeochemical cycle: input from phytolith studies, C. R. Geosci., 344, 739-746, 2012.

Kendrick, K. J. and Graham, R. C.: Pedogenic silica accumulation in chronosequence soils, Southern California, Soil Sci. Soc. Am. J., 68, 1295-1303, 2004.

Kendzia, G., Reißmann, R., and Neumann, T.: Targeted development of wetland habitats for nature conservation fed by natural inflow in the post-mining landscape of Lusatia, World Min., 60, 88-95, 2008.

Kodama, H. and Ross, G. J.: Tiron dissolution method used to remove and characterize inorganic components in soils, Soil Sci Soc. Am. J., 55, 1180-1187, 1991.

Liu, X., Colman, S. M., Brown, E. T., Minor, E. C., and Li, H.: Estimation of carbonate, total organic carbon, and biogenic silica content by FTIR and XRF techniques in lacustrine sediments, J. Paleolimnol. 50, 387-398, 2013.

Loucaides, S., Behrends, T., and Van Cappellen, P.: Reactivity of biogenic silica: Surface versus bulk charge density, Geochim. Cosmochim. Ac. 74, 517-530, 2010.

Ma, J. F. and Yamaji, N.: Functions and transport of silicon in plants, Cell. Mol. Life Sci., 65, 3049-3057, 2008.

McKeague, J. A. and Cline, M. G.: Silica in soil solutions I. The form and concentration of dissolved silica in aqueous extracts of some soils, Can. J. Soil Sci., 43, 70-82, 1963.

Meisterfeld, R.: Order Arcellinida Kent, 1880, in: The illustrated guide to the Protozoa, edited by: Lee, J. J., Leedale, G. F., and Bradbury, P., 827-860, Society of Protozoologists, Lawrence, KS, USA, 2002. 
Meunier, J. D., Colin, F., and Alarcon, C.: Biogenic silica storage in soils, Geology, 27, 835-838, 1999.

Meunier, J. D., Barboni, D., Anwar-ul-Haq, M., Levard, C., Chaurand, P., Vidal, V., Grauby, O., Huc, R., Laffont-Schwob, I., Rabier, J., and Keller, C.: Effect of phytoliths for mitigating water stress in durum wheat, New Phytol., 215, 229-239, https://doi.org/10.1111/nph.14554, 2017.

Mortlock, R. A. and Froelich, P. N.: A simple method for the rapid determination of biogenic opal in pelagic marine sediments, Deep-Sea Res., 36, 1415-1426, 1989.

Pienitz, R., Douglas, M. S., Smol, J. P., Huttunen, P., and Meriläinen, J.: Diatom, chrysophyte and protozoan distributions along a latitudinal transect in Fennoscandia, Ecography, 18, 429-439, 1995.

Puppe, D., Kaczorek, D., Wanner, M., and Sommer, M.: Dynamics and drivers of the protozoic Si pool along a 10-year chronosequence of initial ecosystem states, Ecol. Eng., 70, 477-482, 2014.

Puppe, D., Ehrmann, O., Kaczorek, D., Wanner, M., and Sommer, M.: The protozoic Si pool in temperate forest ecosystems - Quantification, abiotic controls and interactions with earthworms, Geoderma, 243-244, 196-204, 2015.

Puppe, D., Höhn, A., Kaczorek, D., Wanner, M., and Sommer, M.: As Time Goes By - Spatiotemporal Changes of Biogenic Si Pools in Initial Soils of an Artificial Catchment in NE Germany, Appl. Soil Ecol., 105, 9-16, 2016.

Rosén, P., Vogel, H., Cunningham, L., Reuss, N., Conley, D. J., and Persson, P.: Fourier transform infrared spectroscopy, a new method for rapid determination of total organic and inorganic carbon and biogenic silica concentration in lake sediments, J. Paleolimnol., 43, 247-259, 2010.

Russell, D. J., Hohberg, K., and Elmer, M.: Primary colonisation of newly formed soils by actinedid mites, Soil Org. 82, 237-251, 2010.

Saccone, L., Conley, D. J., Likens, G. E., Bailey, S. W., Buso, D. C., and Johnson, C. E.: Factors that control the range and variability of amorphous silica in soils in the Hubbard Brook Experimental Forest, Soil Sci. Soc. Am. J., 72, 1637-1644, 2008.

Sangster, A. G.: Anatomical features and silica depositional patterns in the rhizomes of the grasses Sorghastrum nutans and Phragmites australis, Can. J. Botany, 61, 752-761, 1983.

Sangster, A. G., Hodson, M. J., and Tubb, H. J.: Silicon deposition in higher plants, 85-113, in: Silicon in agriculture (Vol. 8), edited by: Datnoff, L. E., Snyder, G. H., and Korndörfer, G. H., Elsevier, Amsterdam, The Netherlands, 2001.

Sauer, D., Saccone, L., Conley, D. J., Herrmann, L., and Sommer, M.: Review of methodologies for extracting plant-available and amorphous Si from soils and aquatic sediments, Biogeochemistry, 80, 89-108, 2006.

Schaaf, W., Biemelt, D., and Hüttl, R. F.: Initial development of the artificial catchment 'Chicken Creek' - monitoring program and survey 2005-2008. Ecosystem Development 2, edited by: Hüttl, R. F., Schaaf, W., Biemelt, D., and Gerwin, W., 194 pp., 2010.

Schachtschabel, P. and Heinemann, C. G.: Wasserlösliche Kieselsäure in Lößböden, Z. Pflanzenern. Bodenk., 118, 22-35, 1967.

Schlichting, E., Blume, H. P., and Stahr, K.: Soils Practical, Blackwell, Berlin, Wien, Germany, Austria, 295 pp., 1995

Schneider, A., Gerke, H. H., Maurer, T., and Nenov, R.: Initial hydro-geomorphic development and rill network evolution in an artificial catchment, Earth Surf. Proc. Land., 38, 1496-1512, 2013.

Schönborn, W., Petz, W., Wanner, M., and Foissner, W.: Observations on the Morphology and Ecology of the Soil-Inhabiting Testate Amoeba Schoenbornia humicola (Schönborn, 1964) Decloitre, 1964 (Protozoa, Rhizopoda), Arch. Protistenkd., 134, 315-330, 1987.

Sommer, M., Kaczorek, D., Kuzyakov, Y., and Breuer, J.: Silicon pools and fluxes in soils and landscapes - a review, J. Plant Nutr. Soil Sci., 169, 310-329, 2006.

Sommer, M., Jochheim, H., Höhn, A., Breuer, J., Zagorski, Z., Busse, J., Barkusky, D., Meier, K., Puppe, D., Wanner, M., and Kaczorek, D.: Si cycling in a forest biogeosystem - the importance of transient state biogenic Si pools, Biogeosciences, 10, 4991-5007, https://doi.org/10.5194/bg-10-4991-2013, 2013.

Song, Z., Wang, H., Strong, P. J., Li, Z., and Jiang, P.: Plant impact on the coupled terrestrial biogeochemical cycles of silicon and carbon: implications for biogeochemical carbon sequestration, Earth-Sci. Rev., 115, 319-331, 2012.

Street-Perrott, F. A., and Barker, P. A.: Biogenic silica: a neglected component of the coupled global continental biogeochemical cycles of carbon and silicon, Earth Surf. Proc. Land. 33, 14361457, 2008.

Struyf, E. and Conley, D. J. Emerging understanding of the ecosystem silica filter, Biogeochemistry, 107, 9-18, 2012.

Struyf, E., Smis, A., Van Damme, S., Garnier, J., Govers, G., Van Wesemael, B., Conley, D. J, Batelaan, O., Frot, E., Clymans, W., Vandevenne, F., Lancelot, C., Goos, P., and Meire, P.: Historical land use change has lowered terrestrial silica mobilization, Nat. Commun. 1, 129, https://doi.org/10.1038/ncomms1128, 2010.

Tréguer, P. J. and De La Rocha, C. L.: The world ocean silica cycle, Ann. Rev. Mar. Sci., 5, 477-501, 2013.

Tréguer, P. and Pondaven, P.: Global change: silica control of carbo dioxide, Nature, 406, 358-359, 2000.

Vandevenne, F. I., Barão, L., Ronchi, B., Govers, G., Meire, P., Kelly, E. F., and Struyf, E.: Silicon pools in human impacted soils of temperate zones, Global Biogeochem. Cy., 29, 1439 1450, 2015.

Wanner, M. and Elmer, M.: "Hot spots" on a new soil surface - how do testate amoebae settle down?, Acta Protozool., 48, 281-289, 2009.

Wanner, M., Elmer, M., Sommer, M., Funk, R., and Puppe, D.: Testate amoebae colonizing a newly exposed land surface are of airborne origin, Ecol. Indic., 48, 55-62, 2015.

Wanner, M., Seidl-Lampa, B., Höhn, A., Puppe, D., Meisterfeld, R., and Sommer, M.: Culture growth of testate amoebae under different silicon concentrations, Eur. J. Protistol., 56, 171-179, 2016.

Watteau, F. and Villemin, G.: Ultrastructural study of the biogeochemical cycle of silicon in the soil and litter of a temperate forest, Eur. J. Soil Sci., 52, 385-396, 2001.

Wilding, L. P. and Drees, L. R.: Biogenic opal in Ohio soils, Soil Sci. Soc. Am. J., 35, 1004-1010, 1971.

Zaplata, M. K., Fischer, A., and Winter, S.: Vegetation dynamics, in: Ecosystem development 2, edited by: Schaaf, W., Biemelt, D., Hüttl, R. F., Brandenburg University of Technology CottbusSenftenberg, Germany, 2010. 